\title{
Prevalent Safety Hazards and Safety Practices in Maritime Transportation in Selected States in Southern Nigeria
}

\author{
Selema M. Nwoye ${ }^{1,2}$, Charles Oyegun', John N. Ugbebor ${ }^{1,2}$ \\ ${ }^{1}$ Center for Occupational Health, Safety and Environment, University of Port Harcourt, Port Harcourt, Nigeria \\ ${ }^{2}$ Institute of Petroleum Engineering Studies, University of Port Harcourt, Port Harcourt, Nigeria \\ Email: snw2010@yahoo.com
}

How to cite this paper: Nwoye, S.M., Oyegun, C. and Ugbebor, J.N. (2019) Prevalent Safety Hazards and Safety Practices in Maritime Transportation in Selected States in Southern Nigeria. Open Journal of Safety Science and Technology, 9, 83-92. https://doi.org/10.4236/ojsst.2019.93006

Received: July 2, 2019

Accepted: August 9, 2019

Published: August 12, 2019

Copyright (๑) 2019 by author(s) and Scientific Research Publishing Inc. This work is licensed under the Creative Commons Attribution International License (CC BY 4.0).

http://creativecommons.org/licenses/by/4.0/

\begin{abstract}
This study seeks to determine existing safety hazards and practices in the inland water transportation sector in selected states of southern Nigeria. A cross-sectional research design was adopted for the study and the target population for the study included the operators, commuters and regulators of inland water transportation in the study areas. Data were collected through questionnaires, field observations and oral interviews. A total of 2375 questionnaires were distributed across the six states. The study showed that a wide range of maritime safety hazards and practices bedeviled the inland water transportation sector in Nigeria. The findings of the study showed that the use of incompetent boat operators was the most prevailing maritime hazard in the study area, because it ranked highest, with $72.6 \%$ of respondents in agreement, while non-compliance to alcohol and drug policies by operators, no use of journey management forms and safety briefs rarely conducted before departure were the highest ranked unsafe practices with $70.8 \%, 72.7 \%$ and $72 \%$ respondents in agreement respectively. The study recommended that relevant authorities, such as Nigerian Maritime Administration and Safety Agency (NIMASA) and Nigerian Inland Waterways Authority (NIWA) should provide competent and trained boat operators, construct standard jetties, ensure standard and routinely maintained boats are used and ensure maritime safety standards and regulations are adhered to by boat operators and maritime workers to prevent incidents and breakdown of boats along waterways in the study area.
\end{abstract}

\section{Keywords}

Safety Hazards, Safety Practices, Maritime Transportation 


\section{Introduction}

Transportation is one of the most important catalysts for socio-economic development of any place (Akali and Idoko 2010) [1]. The developments in transportation and improvements in the various modes of same have an impact on not only economic and socio-cultural activities; but also play a major role in spatial organization and ordering globally. Inland Waterways Transport (IWT) is the movement of people and goods along inland waterways (Fellinda, 2006; Obeta, 2014) [2] [3].

Nigeria being a coastal nation is endowed with a large stretch of inland navigable waters stretching over $10,000 \mathrm{~km}$. The navigable inland water comprises of rivers, lakes, lagoons, creeks and intra-coastal waters (Aderemo and Mogaji, 2010) [4]. Inland water transportation provides a cost-effective, logistically efficient and environment-friendly mode of transport whose development as a supplementary mode would enable diversion of traffic from over-congested roads and railways, contribute to economic and social development (Ojile, 2006; Obeta 2014) [3] [5].

Despite potentials in the nation's inland waterways, the sector in Nigeria has had a long history of neglect by both the government and the private sector (Azenda, 2013; Akogun, 2014; Iheamnachor, 2014; NBS, 2014; Oyadongha, 2014; Tosin, 2014) [6]-[11]. Little efforts have been made to develop inland water transport facilities. This stems largely from policy inconsistency, limited private sector involvement, and conflicts by agencies involved in the management of inland water transport in Nigeria (Abam, 2004) [12]. The sector has been regarded as one of the most dangerous in Nigeria owing to the problems enumerated below; Sea piracy is presently very common, hence leading to loss of life and properties causing huge economic and commercial losses to Communities, Local government areas, States and Nigeria as a nation (Obeta, 2014) [3].

Nevertheless, whereas sea piracy and other insecurities associated with inland water transport appear to be on the decrease globally, it is increasing in Nigeria. This situation has been worsened by neglect by successive governments in Nigeria to approach insecurity problems head-on (Akogun, 2014; Oyadongha, 2014) [7] [10].

Ademiluyi, Afolabi \& Fashola (2016) [13] in their study "Analysis of intra-city water transportation in Lagos state" which was necessitated by the regular traffic congestion usually experienced in Lagos state metropolis daily. Primary and secondary data are used with descriptive statistics such as percentages to present analyzed results. Spearman's correlation was used to analyze the relationships between different factors, like frequency of using the water ways for transportation, educational level and income category of the respondents. The findings from the study showed that more than $58 \%$ of the sampled population acknowledged that they use the water transportation daily. While more than half of the respondents (52\%) opined that the state of the water transportation system was very bad. The study revealed the following; poor jetty and ferries construction, 
poor safety and security management, exorbitant transport fares. The researchers recommended that there is an important need for more researches to be conducted in the area to enhance the development of operational techniques and encourage the use of technology to ensure safety of commuters, operators and water transportation infrastructures in the state.

The question on the lips of many transport industry operators is "when will the inland waterways system be developed in Nigeria". Across the country, the potentials of this sub-sector have remained untapped. This study therefore seeks to evaluate the prevalent safety hazards and the safety practices in the inland water transportation sector in the study area. The researcher was inspired to undertake this study on the need to unravel the cause of the underdevelopment and underutilization of the inland water ways in Nigeria despite been endowed with a long stretch of navigable waters. In other to carry out this study, research questions were formulated to address the stated problems.

\section{Materials and Method}

\subsection{Study Area}

The study was limited to selected coastal states in Nigeria, namely; Anambra, Bayelsa, Cross River, Lagos, Ondo and Rivers States. A reason for selecting these states borders on the fact that this research looked at the country's maritime transport sector's safety hazards and practices. These selected states rely primarily on marine transportation to complement other available transportation means. Nigeria is a coastline nation with a coastline of $853 \mathrm{~km}$ and a land mass of about 923,768 sq.km. Its coastline lies on the Gulf of Guinea in the southern part and it is bordered by Lake Chad in the north-eastern part, while on the western part it is bordered by Republic of Benin and Niger Republic on the North. Nigeria is situated geographically between longitude $3^{\circ} \mathrm{E}$ and $15^{\circ} \mathrm{E}$, and latitude $4^{\circ} \mathrm{N}$ and $14^{\circ} \mathrm{N}$ (Efe, 2010) [14].

The coastal, area lies on a low plain of not more than $300 \mathrm{~cm}$ above the mean sea level and it is predominantly covered with swamps (mangrove and fresh water) lagoon mashes, sand dunes, beach ridges and tidal channels. This zone experiences a climatic condition predominated by tropical climate, consisting of rainy season from April to November and dry season from December to March (Efe, 2010) (Figure 1).

\subsection{Research Design}

The research design adopted in the study was the cross-sectional research design. The cross-sectional research design was used because it allows the investigator to measure the outcome and the exposures in the study participants at the same time. To achieve this, the researcher employed a structured instrument which was administered to regulators, operators and commuters of the inland waterways to assess their perception, knowledge and awareness of the risk inherent in maritime transportation and incident records. 


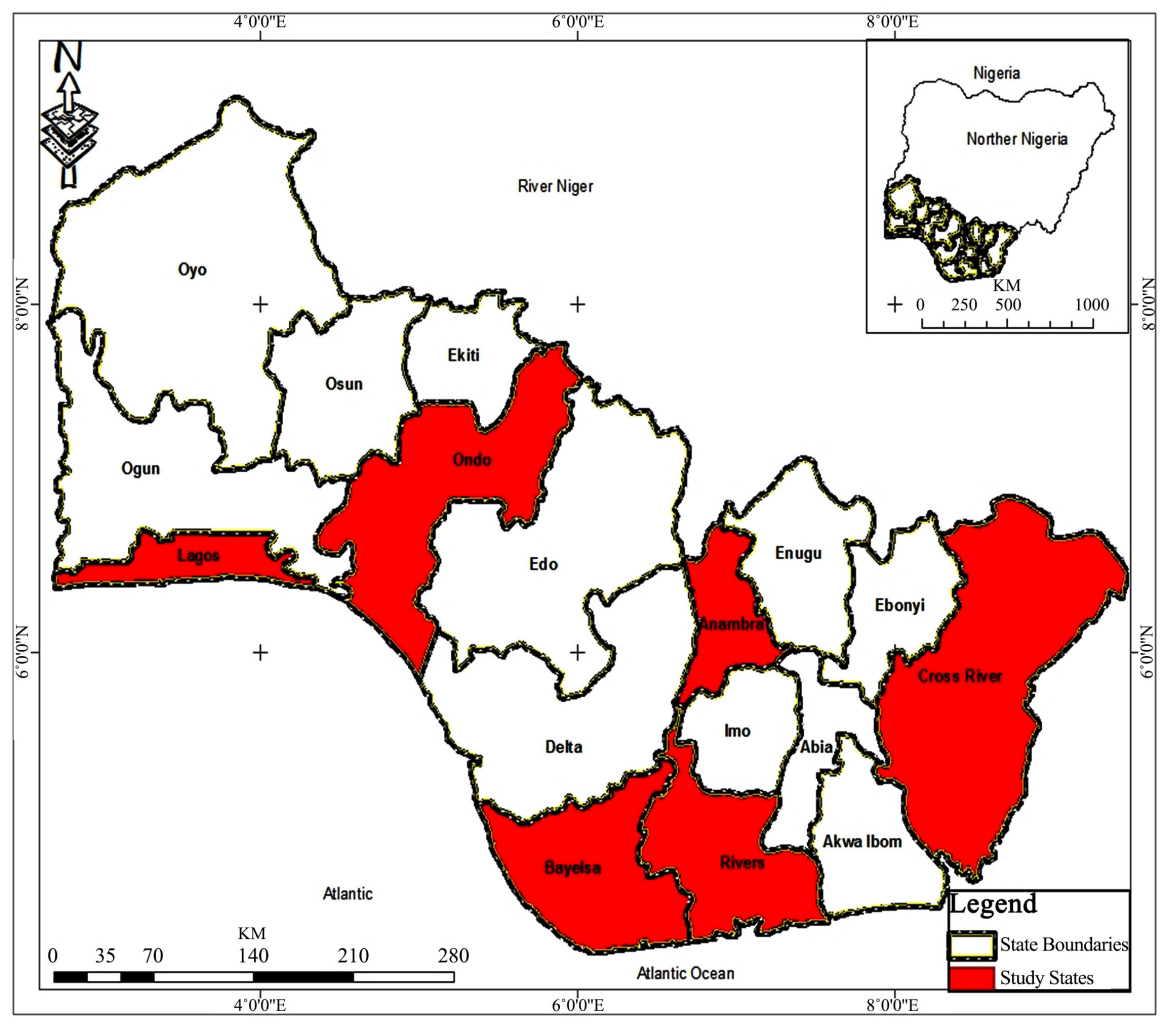

Figure 1. Southern Nigeria showing study states. Source: Modified after, federal ministry of lands, housing and urban development (2010) [15].

\subsection{Sample and Sampling Technique}

\subsubsection{Target Population}

The target population for the study included the operators, commuters and regulators of inland water transportation in the study areas. The justification for targeting this population is that the researcher felt that these populations are those who frequently use the inland water ways (Celik \& Cebi, 2009; Tzannatos, 2010; Progoulaki \& Roe, 2011) [16] [17] [18].

\subsubsection{Sample Size}

Taro Yamane equation was used to generate an appropriate sample size for the study using Equation (2.1) below:

$$
n=N / 1+N\left(\mathrm{e}^{2}\right)
$$

where $n=$ the sample size;

$$
\begin{aligned}
& N=\text { the total population size; } \\
& \text { e = sampling error (in this case } 0.05 \text { ); } \\
& 1=\text { constant. }
\end{aligned}
$$

\subsubsection{Sampling Technique}

Copies of questionnaire were administered using the systematic random sampling technique. However, for effective administration of the copies of questionnaire, the researcher employed the services of some field research assistants 
for the purpose of distribution.

\subsection{Validity and Reliability of Instrument}

The research instrument was subjected to face and content validation. This was necessitated by the need for the items on the instrument to appear valid and logically linked to the study objectives, while also covering the full range of the issues concerning maritime transportation Safety management.

\section{Results and Discussion}

\subsection{Results}

\subsubsection{Demographic Distribution}

The demographic distribution of respondents, Table 1 showed that $64 \%$, which was 1518 of respondents were male and $36 \%$, which was 857 were female adding up to 2375 were the respondents the instruments were administered to, out of which 2352 were returned. A breakdown of the returned instruments were as follows; 5\%, which was 123 respondents were less or equal to 25 years of age, $35 \%$, totaling 839 respondents were between 26 and 35 years of age, $45 \%$, which was 1069 respondents were between 36 and 45 years of age and 15\%, which was 344 respondents were 46 and above years of age.

\subsubsection{Prevalent Safety Hazards in Maritime Transportation}

Presented in Table 2 was the perception of the respondents on prevailing hazards in the maritime transportation sector in the study area. The result showed that the use of incompetent boat operators was the most prevailing maritime hazard in the study area, because it ranked highest (1), with $72.6 \%$ of respondents agreeing, $19.6 \%$ disagreeing and $7.8 \%$ were undecided, closely followed was poorly constructed jetties which ranked second (2) as $73 \%$ of the respondents were in agreement and non-provision of lighting gadgets on boats also ranked second (2) with $72.1 \%$ of respondents in agreement. This was followed by inadequate navigational route signs with $70.8 \%$ in agreement on the fourth (4) position, water hyacinth presence with $69.6 \%$ of respondents in agreement ranked fifth (5) and boats/vessels wrecked and abandoned on the waterway with $72.9 \%$ in agreement ranked sixth (6).

\subsubsection{Nature of Safety Practices in the Maritime Transportation Sector}

Shown in Table 3 was the perception of the respondents on how safety is practiced in the maritime transportation sector in the study area. The result showed that there is no compliance to alcohol and drug policies by operators, no use of journey management forms and safety briefs rarely conducted before departure were the highest (1) ranked unsafe practices by the respondents with $70.8 \%$, $72.7 \%$ and $72 \%$ in agreement respectively, while $21 \%, 19.2 \%$ and $19.5 \%$ respectively disagreed. Operators made sure life jackets were worn properly before departure ranked fourth (4), with 19.9 percent agreeing and 72.1\% disagreeing. Ranked (5) fifth (with $69.6 \%$ disagreeing was that communication gadgets were 
provided on boats, $10.8 \%$ agreed while 19.6 were undecided. Ranked sixth (6) with $72.6 \%$ of respondents disagreeing was that life jackets were provided in boats, while $7.7 \%$ agreed and $19.6 \%$ were undecided.

Table 1. Demographic distribution of respondents.

\begin{tabular}{|c|c|c|c|}
\hline Variables & Option & Frequency & Percentage \\
\hline \multirow{2}{*}{ Gender } & Male & 1518 & 63.9 \\
\hline & Female & 857 & 36.1 \\
\hline \multirow{4}{*}{ Age } & $\geq 25$ years & 123 & 5.2 \\
\hline & 26 - 35 years & 839 & 35.3 \\
\hline & 36 - 45 years & 1069 & 45 \\
\hline & $\leq 46$ years & 344 & 14.5 \\
\hline \multirow{5}{*}{ Category } & Local Operators & 291 & 12 \\
\hline & IOC Commuters & 209 & 8.8 \\
\hline & Regulators & 24 & 1 \\
\hline & Local Boat Commuters & 1833 & 77 \\
\hline & IOC Operators & 18 & 1 \\
\hline \multirow{2}{*}{ Jetties } & IOC & 5 & 21.7 \\
\hline & LOCAL & 18 & 78.3 \\
\hline \multirow{5}{*}{ States } & ANAMBRA & 393 & 16.5 \\
\hline & BAYELSA & 398 & 16.8 \\
\hline & CROSS RIVER & 395 & 16.6 \\
\hline & LAGOS & 399 & 16.8 \\
\hline & ONDO & 392 & 16.5 \\
\hline \multirow{5}{*}{$\begin{array}{c}\text { Years of Experience for } \\
\text { Operators }\end{array}$} & RIVERS & 398 & 16,8 \\
\hline & $\leq 5$ & 54 & 16 \\
\hline & $6-10$ & 126 & 38 \\
\hline & $11-15$ & 82 & 25 \\
\hline & $\geq 16$ & 71 & 21 \\
\hline
\end{tabular}

Legend: IOC-International Oil/gas Company. Source: compilation from authors field work, 2018.

Table 2. Prevalent safety hazards in the maritime transportation sector.

\begin{tabular}{llllllllll}
\hline S/N & $\begin{array}{l}\text { Maritime Transport } \\
\text { Hazards-Items }\end{array}$ & \multicolumn{1}{c}{ A } & D & UD & $\begin{array}{r}\text { Sample } \\
\text { Size }\end{array}$ & $\begin{array}{l}\text { Grand } \\
\text { Mean }\end{array}$ & Rank & Remark \\
\hline 1 & $\begin{array}{l}\text { Jetties were poorly } \\
\text { constructed in the study } \\
\text { area. }\end{array}$ & $\begin{array}{l}1714 \\
(73 \%)\end{array}$ & $\begin{array}{l}452 \\
(19.2 \%)\end{array}$ & $\begin{array}{l}186 \\
(7.9 \%)\end{array}$ & 2352 & 3.89 & 2 & Agreed \\
2 & $\begin{array}{l}\text { Water hyacinth } \\
\text { hindered free flow of } \\
\text { water way traffic. }\end{array}$ & $\begin{array}{l}1636 \\
(69.6 \%)\end{array}$ & $\begin{array}{l}459 \\
(19.5 \%)\end{array}$ & $\begin{array}{l}257 \\
(10.9 \%)\end{array}$ & 2352 & 3.8 & 5 & Agreed \\
3 & $\begin{array}{l}\text { Lighting gadgets were } \\
\text { not provided on boats. }\end{array}$ & $\begin{array}{l}1697 \\
(72.1 \%)\end{array}$ & $\begin{array}{l}445 \\
(18.9 \%)\end{array}$ & $\begin{array}{l}210 \\
(8.9 \%)\end{array}$ & 2352 & 3.89 & 2 & Agreed \\
\hline
\end{tabular}




\section{Continued}

\begin{tabular}{|c|c|c|c|c|c|c|c|c|}
\hline 4 & $\begin{array}{l}\text { Inadequate route signs } \\
\text { constitute major } \\
\text { navigational hazards in } \\
\text { maritime transport. }\end{array}$ & $\begin{array}{l}1666 \\
(70.8 \%)\end{array}$ & $\begin{array}{l}495 \\
(21 \%)\end{array}$ & $\begin{array}{l}191 \\
(8.1 \%)\end{array}$ & 2352 & 3.86 & 4 & Agreed \\
\hline 5 & $\begin{array}{l}\text { Incompetent boat } \\
\text { operators constitute a } \\
\text { major hazard to marine } \\
\text { transport. }\end{array}$ & $\begin{array}{l}1708 \\
(72.6 \%)\end{array}$ & $\begin{array}{l}461 \\
(19.6 \%)\end{array}$ & $\begin{array}{l}183 \\
(7.8 \%)\end{array}$ & 2352 & 3.9 & 1 & Agreed \\
\hline 6 & $\begin{array}{l}\text { Wrecked and abandoned } \\
\text { vessels in the waterways } \\
\text { constitute major hazards. }\end{array}$ & $\begin{array}{l}1714 \\
(72.9 \%)\end{array}$ & $\begin{array}{l}242 \\
(10.3 \%)\end{array}$ & $\begin{array}{l}396 \\
(16.8 \%)\end{array}$ & 2352 & 3.75 & 6 & Agreed \\
\hline
\end{tabular}

Legend: A-Agreed; D-Disagreed; UD_Undecided. Source: Authors field work/analyses, 2018.

Table 3. Safety practices in the maritime transportation sector.

\begin{tabular}{|c|c|c|c|c|c|c|c|c|}
\hline $\mathrm{S} / \mathrm{N}$ & $\begin{array}{c}\text { Safety } \\
\text { Practices-Items }\end{array}$ & A & $\mathrm{D}$ & UD & Total & $\begin{array}{l}\text { Grand } \\
\text { Mean }\end{array}$ & Rank & Remarks \\
\hline 1 & $\begin{array}{l}\text { Life jackets were } \\
\text { provided in boats. }\end{array}$ & $\begin{array}{l}1714 \\
(72.9 \%)\end{array}$ & $\begin{array}{l}452 \\
(19.2 \%)\end{array}$ & $\begin{array}{l}186 \\
(7.9 \%)\end{array}$ & 2352 & 2.4 & 6 & Disagreed \\
\hline 2 & $\begin{array}{l}\text { Operators ensure life } \\
\text { jackets were properly } \\
\text { worn before take-off. }\end{array}$ & $\begin{array}{l}459 \\
(19.5 \%)\end{array}$ & $\begin{array}{l}1636 \\
(69.5 \%)\end{array}$ & $\begin{array}{l}257 \\
(10.9 \%)\end{array}$ & 2352 & 2.8 & 4 & Disagreed \\
\hline 3 & $\begin{array}{l}\text { Journey management } \\
\text { forms were handled } \\
\text { trivially before } \\
\text { take-off. }\end{array}$ & $\begin{array}{l}1714 \\
(72.7 \%)\end{array}$ & $\begin{array}{l}242 \\
(10.3 \%)\end{array}$ & $\begin{array}{l}396 \\
(16.8 \%)\end{array}$ & 2352 & 3.8 & 1 & Agreed \\
\hline 4 & $\begin{array}{l}\text { Safety briefings were } \\
\text { rarely carried out } \\
\text { before take-off. }\end{array}$ & $\begin{array}{l}1697 \\
(72.2 \%)\end{array}$ & $\begin{array}{l}444 \\
(18.9 \%)\end{array}$ & $\begin{array}{l}211 \\
(9 \%)\end{array}$ & 2352 & 3.8 & 1 & Agreed \\
\hline 5 & $\begin{array}{l}\text { Alcohol and drug } \\
\text { policy were not } \\
\text { adhered to by } \\
\text { operators. }\end{array}$ & $\begin{array}{l}1666 \\
(70.9 \%)\end{array}$ & $\begin{array}{l}495 \\
(21 \%)\end{array}$ & $\begin{array}{l}191 \\
(8.1 \%)\end{array}$ & 2352 & 3.8 & 1 & Agreed \\
\hline 6 & $\begin{array}{l}\text { Communication } \\
\text { gadgets were } \\
\text { provided on boats. }\end{array}$ & $\begin{array}{l}183 \\
(7.8 \%)\end{array}$ & $\begin{array}{l}1708 \\
(72.6 \%)\end{array}$ & $\begin{array}{l}461 \\
(19.6 \%)\end{array}$ & 2352 & 2.5 & 5 & Disagreed \\
\hline
\end{tabular}

Legend: A-Agreed; D—Disagreed; UD—Undecided. Source: Authors field work/analyses, 2018.

\subsection{Discussion}

This study showed that the inland water transportation sector in Nigeria is been bedeviled by a wide range of maritime safety hazards including; use of incompetent boat operators, poorly constructed jetties, presence of waste materials (plastic materials) and water hyacinths on water ways, boats not equipped with lighting gadgets, no navigational route signs along sail course, presence of wrecked and abandoned boat along water ways. These hazards have impeded the growth and development of the inland waterways transportation in Nigeria and have led to the underutilization of the sector despite the huge socio-economic potential it possesses. These findings corroborate that of Aderemo \& Mogaji, (2010) [4]; Ezenwaji, (2010) [19]; and Obed, 2013 [20]; who found in their various studies 
that most jetties in Nigeria and indeed Africa are poorly built. However, Tzannatos (2010) [17] had a different finding on the issue, as he stated in his study that building well-constructed jetties are the first necessary work to do before establishing the maritime industry. The same applies to the other areas investigated. According to Victor's findings (2014) [21]; water hyacinth is one of the obstacles to inland water transport in the developing world, especially in the tropics, due to geomorphic processes that favor it and lack of adequate waterway management maintenance (Aderemo \& Mogaji, 2010) [4]. Toffoli, Lefevre, Bitner-Gregersen and Monbaliu, (2005) [22]; Ezenwaji, (2010) [19] \& Obed, (2013) [20] indicated that poor lighting systems can lead to severe risks, especially during bad weather, early evenings or rainfall. This leads to accidents, especially when compounded by inadequate signs along major navigational routes. Ezenwaji, 2010; Obed, 2013; Obeta, 2014 in their studies stressed that poor waterway signs lead to many accidents due to navigational disruption. These findings are consistent with the findings of the National Inland Waterways Authority (NIWA, 2010) [23]; Obed (2013); and Obeta (2014), but disagree with the findings of Akogun (2014), which suggested that boat operation could be learned as a craft and not only through academic qualification.

The study has also identified several unhealthy safety practices which have contributed to the underdevelopment and nose dive of the sector including; no compliance to established safety code of conduct in jetties such as adherence to drug and alcohol policy, safety briefs were rarely conducted before take-off, journey management forms were handled trivially, personal floatation devices (life jacket) were not adequately provided and were not properly worn. These poor safety practices are perceived to be responsible for the high incident rate in maritime transport. These findings are similar to findings reported in the following studies; Oyadongha, 2014; Iheamnachor, 2014 and Akogun, 2014.

\section{Conclusions}

In the developed nations, inland water transport is treated with serious attention, knowing the economic and developmental effects of its collapse. However, there is a sharp contrast in the developing nations in general and Nigeria in particular. One of the issues that have militated against inland water transport in Nigeria is inadequate regulations and policing. This has resulted in increased safety and security risk, poor maritime infrastructural development, non-compliance to international maritime safety codes and procedures, poor safety practices, etc.

Therefore, this study recommends the following:

1) Relevant authorities such as NIMASA and NIWA to ensure provision of competent and trained boat operators and coastal guards, aquatic lifesavers, fire wardens/fighters, safety briefing halls for passengers, personal floatation device (PFD) and lifesaving appliances at beaches and jetties, to prevent maritime incidents and emergencies. 
2) Jetties are properly constructed and equipped with certified personnel and safety equipment, offices, convenient, safe landing and berthing of boats to enable safe embarking/disembarking of passengers and loading/offloading of goods and equipment.

3) Relevant authorities such as NIMASA and NIWA to ensure maritime safety laws are implemented and adhered to.

4) Sensitization and enlightenment campaign of waterfront-dwellers on the effects of dumping of wastes in water.

5) Continuous sensitization and enlightenment campaign programme for all stakeholders (boats/vessels owners, operators, commuters, waterfront dwellers, regulators, etc.), on safe operations on Nigeria inland waterways to eliminate loss of lives and properties.

\section{Contributions}

The study revealed that the level of operators' safety awareness, practices and conditions of jetties affect marine safety.

\section{Conflicts of Interest}

The authors declare no conflicts of interest regarding the publication of this paper.

\section{References}

[1] Akali, K.E. and Idoko, O. (2010) River Transport and Economic Empowerment; an Assessment of Lokoja Crossing Port on the Niger. 53rd Annual Conference of Association of Nigerian Geographers, Lagos.

[2] Fellinda (2006) World's Water Transport Needs Further Development. Journal for Transport Development, 1, 68-72.

[3] Obeta, M.C. (2014) The Characteristics of Inland Water Transport in Nigeria. Journal of Humanities and Social Sciences, 19, 191-126. https://doi.org/10.9790/0837-1934119126

[4] Aderemo, A.J. and Mogaji, S.A. (2010) Rural Transportation of Public Facilities in Nigeria: A Case Study of Edu Local Government Area of Kwara State. Journal of Human Ecology, 29, 171. https://doi.org/10.1080/09709274.2010.11906260

[5] Ojile, M.O. (2006) Draft Report of the Socio-Economic Characteristics for the Idealization of the Port Harcourt-Warri Roads Submitted to Messer Allots Nigeria Limited on Behalf of the Federal Ministry of Works, Abuja. 60.

[6] Azenda, V. (2013) NIWA: Nigeria Lost 296 Lives to Boat Mishaps in 2013 on This Day. Newspaper.

http://www.newsng.com/story-detail.php?title=NIWA:-Nigeria-Lost-296-Lives-to-B oat-Mishaps-in2013\&story $=8048942 \mathrm{c} 32$

[7] Akogun, D. (2014) Why Boats Are Capsizing, People Dying on Lagos Waterways. National Mirror.

[8] Iheamnachor, D. (2014) We Lose Engines, 10 Colleagues to Pirates Monthly-Rivers Boat Operators. Vanguard Newspaper. http://www.vanguardngr.com/2014/12/lose-engines-10-colleagues-pirates-monthlyrivers-boat-operators/\#sthash.GqU46Lks.dpuf 
[9] National Bureau of Statistics (NBS) (2014) Sector Statistics, Transport. http://www.nigerianstat.gov.ng/sectorstat/sectors/Transport

[10] Oyadongha, S. (2014) Piracy Activities Heighten in Niger Delta. Vanguard.

[11] Tosin, J. (2014) Causes and Prevention of Boat Mishap. PM News Nigeria. http://www.pmnewsnigeria.com/2014/05/26/causes-and-prevention-of-boat-misha $\mathrm{p}$

[12] Abams, T.K.S. (2004) Geohydrology with Application to Environmental Management. Charisma Graphic Pub., Port-Harcourt, 126-127.

[13] Ademiluyi, I.A., Afolabi, O.J. and Fashola, O.K. (2016) Analysis of Intra-City Water Transportation in Lagos State. International Journal of Innovative Research and Advanced Studies, 3, 246-254.

[14] Efe, S.I. (2010) Spatial Variation in Acid and Some Heavy Metal Composition of Rainwater Harvesting in the Oil Producing Region of Nigeria. Natural Hazard, 5, 307-319. https://doi.org/10.1007/s11069-010-9529-2

[15] Federal Ministry of Lands, Housing and Urban Development (2010). https://sustainabledevelopment.un.org/partnership/partners/?id=8210

[16] Celik, M. and Cebi, S. (2009) Analytical HFACS for Investigating Human Errors in Shipping Accidents. Accident Analysis and Prevention, 41, 66-75. https://doi.org/10.1016/j.aap.2008.09.004

[17] Tzannatos, E. (2010) Human Element and Accident in Greek Shipping. The Journal of Navigation, 63, 119-127. https://doi.org/10.1017/S0373463309990312

[18] Progoulaki, M. and Roe, M. (2011) Dealing with Multicultural Human Resources in a Socially Responsible Manner: A Focus on the Maritime Industry. WMU Journal of Maritime Affairs, 10, 7-23. https://doi.org/10.1007/s13437-011-0003-0

[19] Ezenwaji, E.E. (2010) Constraints on Effective Water Transportation in Some Riverine Communities of Old Anambra Local Government Area, Anambra State.

[20] Obed, B.C. (2013) A Critical Assessment of the Inland Waterways Operations and Management of the Development of Nigerian Maritime Industry. Greener Journal of Environmental Management and Public Safety, 2, 99. https://doi.org/10.15580/GJEMPS.2013.2.121012320

[21] Victor, F.P. (2014) The Role of the Maritime Industry and Vocational and Technical Education and Training in the Economic Development of Nigeria. IOSR Journal of Humanities and Social Science, 19, 45-50.

http://www.iosrjournals.org/iosr-jhss/papers/Vol19-issue5/Version-5/G019554550. pdf

[22] Toffoli, A., Lefevre, J.M., Bitner-Gregersen, E. and Monbaliu, J. (2005) Towards the Identification of Warning Criteria: Analysis of a Ship Accident Database. Applied Ocean Research, 27, 281-291. https://doi.org/10.1016/j.apor.2006.03.003

[23] National Inland Waterways Authority (NIWA) Annual Reports 2010. 